\title{
Differential expression of HSPA1 and HSPA2 proteins in human tissues; tissue microarray-based immunohistochemical study
}

\author{
Dorota Scieglinska $\cdot$ Wojciech Piglowski • \\ Mykola Chekan • Agnieszka Mazurek • \\ Zdzisław Krawczyk
}

Accepted: 7 February 2011 / Published online: 4 March 2011

(C) The Author(s) 2011. This article is published with open access at Springerlink.com

\begin{abstract}
In the present study we determined the expression pattern of HSPA1 and HSPA2 proteins in various normal human tissues by tissue-microarray based immunohistochemical analysis. Both proteins belong to the HSPA (HSP70) family of heat shock proteins. The HSPA2 is encoded by the gene originally defined as testis-specific, while HSPA1 is encoded by the stress-inducible genes (HSPA1A and HSPA1B). Our study revealed that both proteins are expressed only in some tissues from the 24 ones examined. HSPA2 was detected in adrenal gland, bronchus, cerebellum, cerebrum, colon, esophagus, kidney, skin, small intestine, stomach and testis, but not in adipose tissue, bladder, breast, cardiac muscle, diaphragm, liver, lung, lymph node, pancreas, prostate, skeletal muscle, spleen, thyroid. Expression of HSPA1 was detected in adrenal gland, bladder, breast, bronchus, cardiac muscle, esopha-
\end{abstract}

Electronic supplementary material The online version of this article (doi:10.1007/s00418-011-0791-5) contains supplementary material, which is available to authorized users.

D. Scieglinska $(\bowtie) \cdot$ W. Piglowski · A. Mazurek · Z. Krawczyk

Center For Translational Research and Molecular Biology

of Cancer, Maria Skłodowska-Curie Memorial Cancer Center

and Institute of Oncology, Gliwice Branch,

Wybrzeże Armii Krajowej 15, 44-101 Gliwice, Poland

e-mail: dorotas@io.gliwice.pl

M. Chekan

Department of Tumor Pathology, Maria Skłodowska-Curie

Memorial Cancer Center and Institute of Oncology,

Gliwice Branch, Wybrzeże Armii Krajowej 15,

44-101 Gliwice, Poland

\section{Z. Krawczyk}

Department of Organic Chemistry, Bioorganic Chemistry and Biotechnology, Silesian University of Technology,

Gliwice, Poland gus, kidney, prostate, skin, but not in other tissues examined. Moreover, HSPA2 and HSPA1 proteins were found to be expressed in a cell-type-specific manner. The most pronounced cell-type expression pattern was found for HSPA2 protein. In the case of stratified squamous epithelia of the skin and esophagus, as well as in ciliated pseudostratified columnar epithelium lining respiratory tract, the HSPA2 positive cells were located in the basal layer. In the colon, small intestine and bronchus epithelia HSPA2 was detected in goblet cells. In adrenal gland cortex HSPA2 expression was limited to cells of zona reticularis. The presented results clearly show that certain human tissues constitutively express varying levels of HSPA1 and HSPA2 proteins in a highly differentiated way. Thus, our study can help designing experimental models suitable for cell- and tissue-type-specific functional differences between HSPA2 and HSPA1 proteins in human tissues.

Keywords HSP70 family proteins - HSPA2 protein . HSPA1 protein - Cell-type-specific expression - Tissue microarrays $\cdot$ Normal human tissues

\section{Introduction}

Heat shock proteins (HSPs) constitute a large group of chaperone proteins found in virtually all organisms. HSPs are classified into several families on the basis of their molecular size and amino acid sequence similarity. The largest family is HSPA (previously called HSP70; Kampinga et al. 2009) which in humans includes 13 genes. In human cells, genes belonging to this family exhibit highly differentiated expression patterns, intracellular localization and function. Some of them are highly inducible by heat shock and other environmental and endogenous stimuli but 
most are expressed under physiological conditions and their transcription is only moderately affected by stress. Also, at physiological temperature the expression levels of various HSPAs may be significantly divergent, from barely detectable, to reaching up to several percent of cellular protein content.

The knowledge on the expression pattern of HSPA genes in human cells comes from studies performed using cells grown in vitro, from studies of various pathological tissues, or are inferred from animal studies. Although important knowledge has been gathered on the differential expression of HSPA genes in various pathologies, notably in cancer, much less is known about their expression pattern in normal human tissues in vivo. This issue seems to be especially important in the case of two groups of HSPA genes. The first one consists of inducible members of HSPA family, which are believed to be expressed at a very low level (if any) in normal tissues under physiological conditions. The second one groups genes, whose expression was originally ascribed exclusively to specific non-somatic cell types. In the present paper, we performed an immunohistochemical study using tissue microarrays (TMA) containing a broad panel of human normal tissues (Tissue Array Network, Rockville, MD, USA), in search for possible human cell-type-specific expression of HSPA2 and HSPA1 proteins.

The HSPA2 gene was originally characterized (Bonnycastle et al. 1994) as the human counterpart of rodent genes which are specifically and highly expressed in the testis (rat Hst70 gene, Krawczyk et al. 1988a, b; Widlak et al. 1995; Scieglinska et al. 1997, 2004, mouse Hsp70-2 gene, Zakeri et al. 1988; Allen et al. 1996). In human testicular cells, the highest levels of the HSPA2 protein were detected in spermatocytes, spermatids and in the tail of mature spermatozoa (Son et al. 1999; Huszar et al. 2000). It has been suggested that HSPA2 is involved in the late stages of spermatid development (Huszar et al. 2000). Aberrant expression of HSPA2 in testes has been connected with male infertility (Yesilli et al. 2005; Cedenho et al. 2006).

Recently, HSPA2 has attracted increased interest due to its possible involvement in carcinogenesis of non-testicular tissues. In relevant papers, Rohde et al. (2005) reported that HSPA2 is required for cancer cell growth, Garg et al. (2010) found that HSPA2 downregulation suppressed the growth of xenografted urothelial carcinoma cells. It was shown that in cancer cells heat shock stimulates trafficking of HSPA2 protein from cytoplasm to nucleus and its accumulation in centrosomes and nucleoli (Scieglinska et al. 2008). Because transcript and protein encoded by the HSPA2 gene have been found in various tumor cell lines and primary tumors (Rohde et al. 2005; Piglowski et al. 2007; Scieglinska et al. 2008), its involvement in tumorigenesis seems to be recognized.
However, very little is known about the expression and function of the HSPA2 gene in normal somatic cells. Interestingly, Bonnycastle et al. (1994) detected relatively high levels of HSPA2 transcript in numerous human tissues (with exception of the liver) but a subsequent search for HSPA2 protein essentially revealed its insignificant (if any) expression (Son et al. 1999). The discrepancy between the relatively high transcript level and very low level of the corresponding protein can result either from low specificity or/and affinity of polyclonal antibodies used for HSPA2 detection, or from inefficient translation of the HSPA2 transcript, or from the specific mechanisms enabling efficient expression of the gene only in specific cell types. HSPA2 protein could not be detected, in spite of the presence of corresponding mRNA, in HCT116 human colon cancer cell line (Scieglinska et al. 2008), so it seems that post-transcriptional mechanisms may downregulate the expression of HSPA2 in other cell types as well. However, it is possible that similarly as in the testis, where HSPA2 expression is restricted only to a subpopulation of germinal cells (spermatocytes and spermatids), in somatic tissues HSPA2 can also exhibit cell-type-specific expression patterns.

Another protein which has been investigated in the present study is stress-inducible HSPA1. It is a well characterized protein and a large part of the data published on the human HSPA family deals with its major stress-inducible member. In fact, in human tissues two HSPA1 proteins are expressed, namely HSPA1A and HSPA1B, which only differ by two amino acids, and which are believed to be fully interchangeable proteins (Kampinga et al. 2009). They are encoded by two closely linked, intronless and stress-inducible genes, HSPAIA and HSPAIB. Expression of the HSPAIA and HSPA1B genes cannot be distinguished at the protein level and we decided to use the same name HSPAl for both. However, differences in their 3 '-untranslated regions allow analysis of their individual RNA expression profiles. The common view on the activity of stress-inducible HSPAl gene is that it is expressed in unstressed normal cells at low or undetectable levels only and their activation indicates the condition of cellular stress. The HSPA1 protein is accepted as a cytoprotective agent (for review see Calderwood and Ciocca 2008; Schmitt et al. 2007). Expression of HSPA1 can be highly activated by various stressful stimuli and under a broad spectrum of physiopathological conditions. Significant HSPA1 expression has been found in human cancer cells grown in vitro as well as in various primary tumors and metastases [for review see Ciocca and Calderwood (2005)]. However, much less is known to what extent HSPA1 could be expressed in non-stressed human somatic tissues in vivo. No systematic investigation has been performed so far and a vast majority of data comes from research focused on HSPA1 protein expression in primary tumors, in which few 
samples of cancer adjacent tissues were assessed as a control. It has been shown that inducible HSPA1 can be constitutively expressed in selected cell types. For example, HSPA1 was found in epithelial cells of normal human endometrium and ectocervix (Mangurten et al. 1997) and in keratinocytes from differentiating layers of epidermis (Trautinger et al. 1995) while no or only weak expression was detected in surrounding cells. The ability to induce HSPA1 expression can be cell-type-specific as it was shown that in human esophagus heat shock downregulated the HSPAl gene activity (Yagui-Beltran et al. 2001).

The present immunohistochemical study was meant to gather new extensive data on the possible constitutive cell-type-specific expression of the HSPA1 and the HSPA2 proteins in human somatic tissues. We screened samples of 24 normal tissues derived from up to 11 donors. We found that both HSPA2 and HSPA1 proteins are expressed in a cell-type-specific manner and that their expression patterns differ significantly. These results indirectly suggest that in normal tissues these proteins can be involved in the regulation of various, possibly non-overlapping cellular processes. Moreover, our study provides the basis for future investigations concerning cell-typespecific function of these proteins in normal human tissues.

\section{Materials and methods}

Tissues

TMA containing human tissues were purchased from Tissue Array Network (Rockville, USA). In accordance with the manufacturer's information, all tissue samples were fixed in formalin, processed in tissue processor (no more than $24 \mathrm{~h}$ of fixation) and finally embedded in paraffin. The TMA \#BN961 contains 102 spots $(1.5 \mathrm{~mm}$ diameter) of the following 24 tissue types (4 spots for each): adipose, adrenal gland, breast, bronchus, cerebellum, cerebrum, colon, diaphragm, esophagus, heart, kidney, liver, lung, lymph node, ovary, pancreas, prostate, skeletal muscle, skin, small intestine, spleen, stomach, testis and uterus. The second TMA, \#MC5002, contained 500 spots ( $0.6 \mathrm{~mm}$ diameter) of tumor and normal tissue samples, derived from different organs. In total, it contained normal samples (healthy tissues or pathologically normal tissues adjacent to the tumor) from 17 anatomical locations: bladder (5), brain (5), breast (5), colon (5), kidney (5), liver (5), lung (5), lymph node (10), ovary (5), pancreas (5), prostate (5), skin (10), stomach (5), testis (5), thyroid (5), uterus (5). Numerals in parentheses indicate number of samples (each sample derived from a different donor).
Production and purification of rabbit Anti-HSPA2 serum

To generate anti-HSPA2 rabbit polyclonal antibody, C-terminal peptide (NH2-SKLYQGGPGGGGSSGGPT), corresponding to amino acids $611-628$ in the mouse HSPA2 sequence was selected because of the highest level of divergence between HSPAs amino acid sequence (Rosario et al. 1992; Scieglinska et al. 2008). Human HSPA2 peptide corresponding to the selected sequence was not considered as antigenic peptide because of the presence of gycine-rich seven amino acid-long insertion (GGGGSGA) after serine 623. BLAST search indicated high similarity between the human HSPA2 C-terminal peptide and glycine-rich motifs present in other proteins. For immunization, the peptide was C-terminally conjugated with bovine thyroglobulin (Sigma-Genosys Custom Peptide Antisera Facility). The anti-HSPA2 serum was purified by antigen affinity purification as described earlier (Sambrook et al. 1989; Scieglinska et al. 2008). We used frozen human testes as a source of antigen. Testes samples were homogenized on ice in 3-5 volumes of buffer containing $50 \mathrm{mM}$ Tris- $\mathrm{HCl}(\mathrm{pH} 7.5), 150 \mathrm{mM}$ $\mathrm{NaCl}, 0.1 \%$ Nonidet P-40, $50 \mathrm{mM} \mathrm{NaF}, 1 \mathrm{mM}$ DTT, $1 \mathrm{mM}$ PMSF, a protease inhibitor mixture (Complete ${ }^{\mathrm{TM}}$, Roche) and centrifuged at $15,000 \mathrm{~g}$ for $10 \mathrm{~min}$ at $4^{\circ} \mathrm{C}$. Supernatant was aliquoted and total protein content was determined using Protein Assay Kit (BioRad). Protein extract (1.2 mg) was separated by SDS-PAGE on $8 \%$ polyacrylamide gel and immobilized on nitrocellulose membrane. The membrane fragment containing $70 \mathrm{kDa}$ proteins was excised and incubated for $4 \mathrm{~h}$ at RT with rabbit HSPA2-antiserum diluted in $5 \%$ milk in TBS (50 mM Tris (pH 7.0), $150 \mathrm{mM} \mathrm{NaCl}$ ). After incubation with antiserum, the membrane was washed three times for 5 min in TBS buffer supplemented with Tween-20 at a final concentration of $0.025 \%$. Next, antigen bound antibody was eluted by incubation in $200 \mathrm{mM}$ glycine solution ( $\mathrm{pH} 2.8$ ) for $25 \mathrm{~min}$ and neutralized by addition of $1 \mathrm{M}$ Tris ( $\mathrm{pH} 7.5$ ) to a final concentration of $100 \mathrm{mM}$. Aliquots of anti-HSPA2 antibody were stored at $-20^{\circ} \mathrm{C}$. Specificity of each stock of purified anti-HSPA2 serum was confirmed by Western blot and immunocytochemistry.

\section{Western blotting}

Protein extracts from frozen post-surgical human testes (a gift from dr R. Nowak) and from HepG2 and A549 cell lines were prepared on ice in buffer containing $50 \mathrm{mM}$ Tris- $\mathrm{HCl}$ (pH 7.5), $150 \mathrm{mM} \mathrm{NaCl}, 0.1 \%$ Nonidet P-40, $50 \mathrm{mM} \mathrm{NaF}, 1 \mathrm{mM}$ DTT, $1 \mathrm{mM}$ PMSF, a protease inhibitor mixture (Complete ${ }^{\mathrm{TM}}$, Roche). After centrifugation at $15,000 \mathrm{~g}$ for $10 \mathrm{~min}$ at $4^{\circ} \mathrm{C}$, supernatant was aliquoted and total protein content was determined using Protein Assay Kit (BioRad). $30 \mu \mathrm{g}$ of protein extracts were separated by SDS-PAGE on $8 \%$ polyacrylamide gel and immobilized on 
a nitrocellulose membrane (Protran, Whatman, Dassel, Germany). Blots were blocked in 5\% skimmed milk in TTBS (0.25 M Tris-HCl (pH 7.5), 0.1\% Tween-20, $0.15 \mathrm{M}$ $\mathrm{NaCl}$ ) for $60 \mathrm{~min}$ and incubated overnight at $4{ }^{\circ} \mathrm{C}$ with either preimmune rabbit serum $(1: 5,000)$ or anti-HSPA2 rabbit polyclonal serum $(1: 5,000)$ or purified anti-HSPA2 monospecific polyclonal antibody $(1: 100)$. Primary antibodies were detected by goat anti-rabbit horseradish peroxidase conjugated secondary antibody (Pierce) and visualized using SuperSignal1 West Pico Chemiluminescent Substrate Kits (Pierce).

$0.5 \mu \mathrm{g}$ of human recombinant HSPA2-GST fusion protein (Abnova), HSPA6 (StressGen), HSPA1 and HSPA8 (gifts from Prof. A. Żylicz) were separated by SDS-PAGE on $8 \%$ polyacrylamide gel and immobilized on nitrocellulose membrane (Whatman). Immunodetection was performed as described above, as primary antibodies purified antiHSPA2 (1:100) or monoclonal anti-HSPA1 $(1: 1,000$, clone SPA810; StressGen) were used.

\section{Immunohistochemistry}

TMA slides containing paraffin-embedded tissue spots were coated by manufacturer with an extra layer of paraffin to preserve antigenicity. Before deparafinization slides were baked at $60^{\circ} \mathrm{C}$ for $1 \mathrm{~h}$ in an oven on a vertical rack to melt the coated paraffin. To enhance imunohistochemical specificity before immunostaining, antigen retrieval was performed by two 5-min cycles of boiling in $0.01 \mathrm{M}$ citrate buffer in a microwave oven. The endogenous peroxidase activity was blocked with $1 \% \mathrm{H}_{2} \mathrm{O}_{2}$ in PBS and slides were incubated overnight with primary antibodies. The following primary antibodies were used: rabbit monospecific polyclonal anti-HSPA2 (described above), mouse monoclonal anti-Hsp70 SPA810 (StressGen Biotechnologies), mouse monoclonal anti-cytokeratin 10 (Novocastra), mouse monoclonal anti-cytokeratin5/6 (Dako). The immunohistochemistry procedure was performed using an IMPRESS Universal kit (Vector) according to the manufacturer's guidelines; 3,3'-diaminobenzidine (Sigma-Aldrich, Inc.) was applied as a chromogen for visualization of immunoreaction, while hematoxylin was used for counterstaining. Negative controls for specificity of the HSPA2 staining were performed by either omitting the primary antibody or by peptide competition. For the latter one, the HSPA2 antibody in working concentration was preincubated for $1 \mathrm{~h}$ at room temperature with mass excess of the peptide antigen $(1 \mu \mathrm{g})$ used for rabbits immunization. All steps were performed in a humid chamber at room temperature. Both controls gave similar results.

To score the immunohistochemistry, we used the semiquantitative methodology with respect to the intensity of immunological staining. Array spots were scored relative to staining intensity observed in the positive control: testes for HSPA2 and prostate for HSPA1. Bright/dark intensity visible at low magnification $(40 \times)$, and equal to that observed in the positive control-strong staining. Definitively lighter than bright/dark and visible at low magnification $(40 \times)$ moderate staining. Staining that could be disclosed at $100 \times$ magnification-weak staining. Barely visible staining confirmed only at high magnification $(400 \times)$ or lack of signal-no staining. All specimens were analyzed by two separate investigators.

\section{Results}

The expression of HSPA1 and HSPA2 proteins was examined by immunohistochemistry using two commercially available TMAs obtained from Tissue Array Network. The microarray contained multiple spots of various normal human tissues listed in the "Material and methods" section. To determine the expression pattern of the HSPA2 protein in human somatic tissues we used rabbit monospecific polyclonal antibody (Scieglinska et al. 2008). Western blot results confirmed the specificity of anti-HSPA2 antibody as no unspecific binding of the antibody to proteins extracted from human testes and cell lines was detected (Fig. 1b). This antibody also did not cross-react with other members of human HSPA family including stress-inducible HSPA1 and HSPA6 proteins or constitutively expressed HSPA8 protein (Fig. 1c). The expression of inducible HSPA1 protein was evaluated using commercially available antibody (SPA810, StressGen Biotechnologies, Malusecka et al. 2006). As shown in Fig. 1c commonly used SPA-810, did not crossreact to HSPA8 and HSPA2 protein; however, its crossreactivity to HSPA6 was observed (Fig. 1c). The HSPA6 is a strictly inducible member of the HSPA family (Noonan et al. 2007a) and it was shown that at $37^{\circ} \mathrm{C}$ the HSPA6 protein has a very short half-life (Noonan et al. 2007b). Because HSPA6 has never been detected in cells under normal conditions we claim that in normal human tissues only the HSPA1 protein could be detected using SPA810 antibody. Our study reveals that HSPA2 is expressed in a tissue- and cell-typespecific manner, and the expression pattern of this protein is significantly different, as compared to HSPA1. The most relevant results of the analysis are described below and summarized in Table 1. Additionally, pictures of corresponding whole tissue spots stained with H\&E, anti-HSPA2 and antiHSPA1 antibodies captured at low magnification $(40 \times)$ are available in Online Resource 1.

\section{Testis}

The expression pattern of HSPA2 in human testes has been already unequivocally established in earlier studies 
a



d

\section{b}

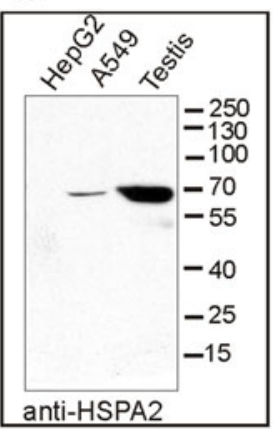

C

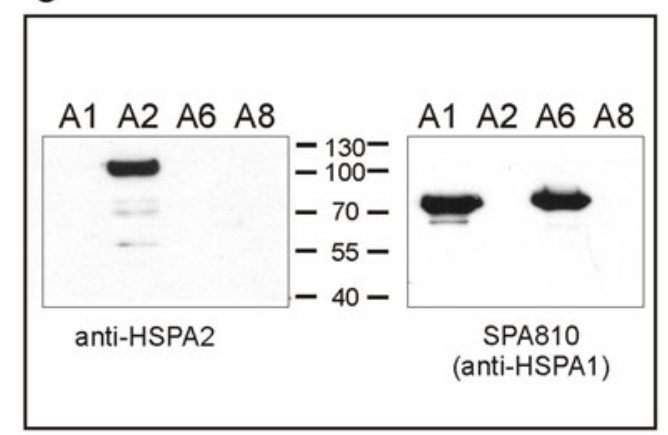

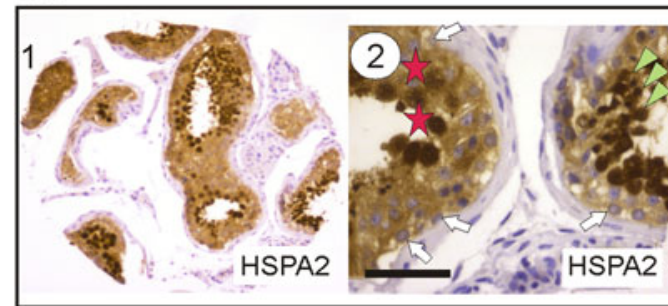



Fig. 1 Specificity of anti-HSPA2 antibody. a Protein extract isolated from human testes was subjected to Western blot analysis. HSPA2 was detected with rabbit preimmune serum (left blot) or unpurified antiHSPA2 rabbit polyclonal serum (right blot). b Protein extracts from human cell lines and human testes were subjected to Western blot analysis. We used proteins from HepG2 and A549 cell lines which previously were identified as not-transcribing and transcribing HSPA2 gene, respectively (Scieglinska et al. 2008). For HSPA2 detection antigen affinity purified anti-HSPA2 antibody was used. c Purified recombinant human HSPA1, HSPA2-GST, HSPA6 and HSPA8 proteins $(0.5 \mu \mathrm{g}$ each) were analyzed by Western blot. Left panel specific detec-

(Son et al. 1999; Huszar et al. 2000). Thus, immunohistochemical examination of testicular tissue ( 9 spots $/ 6$ cases) was used as a positive control. As expected, strong HSPA2 staining was observed in spermatocytes and spermatids, while no signal was found in spermatogonia and in somatic testicular cells (Fig. 1d). Positive signal was not observed when spots were probed with antibody recognizing HSPA1 protein (Fig. 1d, Online Resource 1). This finding indicates that, similarly as in rodents' testes, HSPA1 is not expressed in non-stressed human testicular germ and somatic cells (Izu et al. 2004; Widlak et al. 2007). Peptide competition reaction performed as control of specificity proved highly reliable detection of the HSPA2 protein in testes by our anti-HSPA2 antibody (Fig. 1d).

\section{Skin and breast}

Examination of HSPA2 expression revealed cell type-specific HSPA2 staining in stratified squamous epithelium of skin (14 spots/11 cases). Strong HSPA2 staining was detected in cells constituting the basal layer of epidermis (Fig. 2b, Online Resource 1). Positive signal observed in tion of HSPA2-GST protein with purified anti-HSPA2 antibody. Right panel commercially available anti-HSPA1 antibody (SPA-810) crossreacts with HSPA6 protein. d Immunohistochemical detection of HSPA2 protein in testes. 1 example of testis tissue spot stained with anti-HSPA2 antibody; 2 higher magnification, note strong HSPA2 staining in spermatocytes (red asterisk) and spermaitds (green triangles), no staining in spermatogonia (white arrow); 3 specificity of HSPA2 detection in testes (anti-HSPA2 antibody and peptide competition, for details see "Material and methods" section); 4 testis stained with anti-HSPA1 antibody. Bar $100 \mu \mathrm{m}$

keratinized outermost layer of the epidermis was identified as unspecific by peptide competition reaction (compare Fig. 2b, f). To confirm the identity of the HSPA2-positive cells we stained human skin with antibody-specific for cytokeratin $5 / 6$, a marker of epidermal basal layer (Fig. 2d). Results of the above analysis strongly suggest that HSPA2 is expressed in the basal keratinocytes expressing cytokeratin $5 / 6$, while it is not present in spinal and granular layer keratinocytes which express cytokeratin 10 (Fig. 2d, e). In contrast to the highly focused expression of HSPA2, the expression of HSPA1 was observed in all layers of epidermis (Fig. 2c, Online Resource 1). The above findings were confirmed in a separate experiment performed using postsurgical skin specimens (data not shown).

The expression of HSPA2 was also analyzed in breast tissue ( 9 spots/ 6 cases). We found that HSPA2 is not expressed in normal breast, only in one case a few scattered, weakly stained cells were found (Fig. 2h, Online Resource 1). On the contrary, strong HSPA1 staining was detected in breast glandular epithelium, both in myoepithelial and epithelial cells (Fig. 2i, Online Resource 1). 
Table 1 HSPA2 and HSPA1 expression in human tissues-summary of results

\begin{tabular}{|c|c|c|c|c|c|c|c|}
\hline \multirow[t]{2}{*}{ Tissue } & \multirow{2}{*}{$\begin{array}{l}\text { No cases/ } \\
\text { no spots }\end{array}$} & \multicolumn{2}{|l|}{ HSPA2 } & \multirow[t]{2}{*}{ Cell type/cell layer } & \multicolumn{2}{|l|}{ HSPA1 } & \multirow[t]{2}{*}{ Cell type/cell layer } \\
\hline & & $\mathrm{EST}^{\mathrm{a}}$ & Protein & & $\mathrm{EST}^{\mathrm{b}, \mathrm{c}}$ & Protein & \\
\hline Adipose tissue & $1 / 4$ & 0 & - & & $2975 / 610$ & - & \\
\hline Adrenal gland & $1 / 4$ & 60 & + & $\begin{array}{l}\text { Cortex-zona reticularis cells } \\
\text { (cytoplasm-moderate) }\end{array}$ & $1807 / 391$ & + & $\begin{array}{l}\text { Cortex-zona reticularis cells, } \\
\text { zona fasiculata, zona } \\
\text { glomerulosa } \\
\text { (nucleus_-moderate) }\end{array}$ \\
\hline Bladder & $6 / 9$ & 0 & - & & $907 / 1176$ & + & $\begin{array}{l}\text { Epithelium—all layers } \\
\text { (nucleus—strong) }\end{array}$ \\
\hline Breast & $6 / 9$ & 13 & - & & $750 / 104$ & + & $\begin{array}{l}\text { Myoepithelial and epithelial } \\
\text { cells (strong) }\end{array}$ \\
\hline Bronchus & $1 / 4$ & No data & + & $\begin{array}{l}\text { Epithelium-goblet cells (nucleus- } \\
\text { strong), basal cells (nucleus- } \\
\text { strong), ciliated cells } \\
\text { (cytoplasm, moderate) }\end{array}$ & No data & + & $\begin{array}{l}\text { Epithelium—basal cells } \\
\text { (cytoplasm, } \\
\text { nucleus-moderate) }\end{array}$ \\
\hline Cardiac muscle & $1 / 4$ & 66 & - & & $1885 / 357$ & + & Endothelial cells \\
\hline Cerebellum & $1 / 4$ & No data & + & $\begin{array}{l}\text { White matter cells } \\
\text { (nucleus, cytoplasm—strong) }\end{array}$ & No data & - & \\
\hline Cerebrum & $6 / 9$ & 641 & + & $\begin{array}{l}\text { Glial cells (nucleus, } \\
\text { cytoplasm—strong) }\end{array}$ & $990 / 224$ & - & \\
\hline Colon & $6 / 9$ & 76 & + & $\begin{array}{l}\text { Epithelium_-goblet cells } \\
\text { (nucleus_-moderate); } \\
\text { Smooth muscle fibers of lamina } \\
\text { muscularis mucosae } \\
\text { (cytoplasm, nucleus-moderate) }\end{array}$ & $1113 / 166$ & - & \\
\hline Esophagus & $1 / 4$ & 247 & + & $\begin{array}{l}\text { Epithelium—basal layer cells } \\
\text { (strong) }\end{array}$ & $3364 / 1731$ & + & $\begin{array}{l}\text { Epithelium-all layers } \\
\text { (nucleus, cytoplasm- } \\
\text { moderate) }\end{array}$ \\
\hline Kidney & $6 / 9$ & 198 & + & Cortex-distal tubules (moderate) & $972 / 226$ & + & $\begin{array}{l}\text { Cortex-glomerulus, } \\
\text { Bowman's capsule and } \\
\text { renal tubules (moderate) }\end{array}$ \\
\hline Liver & $6 / 9$ & 4 & - & & $375 / 72$ & - & \\
\hline Lymph node & $11 / 14$ & 0 & - & & $10 / 10$ & - & \\
\hline Prostate & $6 / 9$ & 21 & - & & $1209 / 195$ & + & $\begin{array}{l}\text { Epithelium—basal cells } \\
\text { (nucleus—-strong) }\end{array}$ \\
\hline Skeletal muscle & $1 / 4$ & 27 & - & & $259 / 55$ & - & \\
\hline Skin & $11 / 14$ & 147 & + & $\begin{array}{l}\text { Epidermis—-keratinocytes of basal } \\
\quad \text { layer (nucleus—-strong) }\end{array}$ & $346 / 61$ & + & $\begin{array}{l}\text { Epidermis-keratinocytes } \\
\text { of all layers }\end{array}$ \\
\hline Small intestine & $1 / 4$ & No data & + & $\begin{array}{l}\text { Epithelium_goblet cells } \\
\text { (nucleus-weak), } \\
\text { Paneth cells; smooth muscle fibers } \\
\text { of lamina muscularis mucosae } \\
\text { (cytoplasm, nucleus_-moderate) }\end{array}$ & No data & - & \\
\hline Spleen & $1 / 4$ & 92 & - & & $7469 / 1427$ & - & \\
\hline Stomach & $5 / 5$ & 41 & + & $\begin{array}{l}\text { Epithelium-parietal cells } \\
\quad \text { (spots in cytoplasm—weak) }\end{array}$ & $714 / 165$ & - & \\
\hline Testis & $6 / 9$ & 553 & + & $\begin{array}{l}\text { Spermatocytes and spermatids } \\
\text { (strong) }\end{array}$ & $260 / 42$ & - & \\
\hline Thyroid & $5 / 5$ & 0 & - & & $947 / 315$ & - & \\
\hline
\end{tabular}

Data on relative EST number extracted form UNIGENE database (http://www.ncbi.nlm.nih.gov/unigene)

${ }^{\text {a }}$ Number of EST corresponding to HSPA2 gene per million of transcripts in given tissue

${ }^{\mathrm{b}}$ Number of EST corresponding to HSPA1A gene per million of transcripts in given tissue

${ }^{c}$ Number of EST corresponding to HSPA1B gene per million of transcripts in given tissue 
Fig. 2 Detection of HSPA2 and HSPA1 in epidermis and breast tissue. Skin sections stained with H\&E (a), anti-HSPA2 (b), antiHSPA1 (c), anti-cytokeratin5/6 (d), anti-cytokeratin 10 (e) antibodies; negative control-result of peptide competition reaction $(\mathbf{f})$. Breast sections stained with $\mathrm{H} \& \mathrm{E}(\mathbf{g})$, antiHSPA2 (h) and anti-HSPA1 (i) antibodies. Black triangle points at basal layer of epidermis. Red arrowhead indicates unspecific signal in keratinized zona lucida of epidermis. Bar $100 \mu \mathrm{m}$
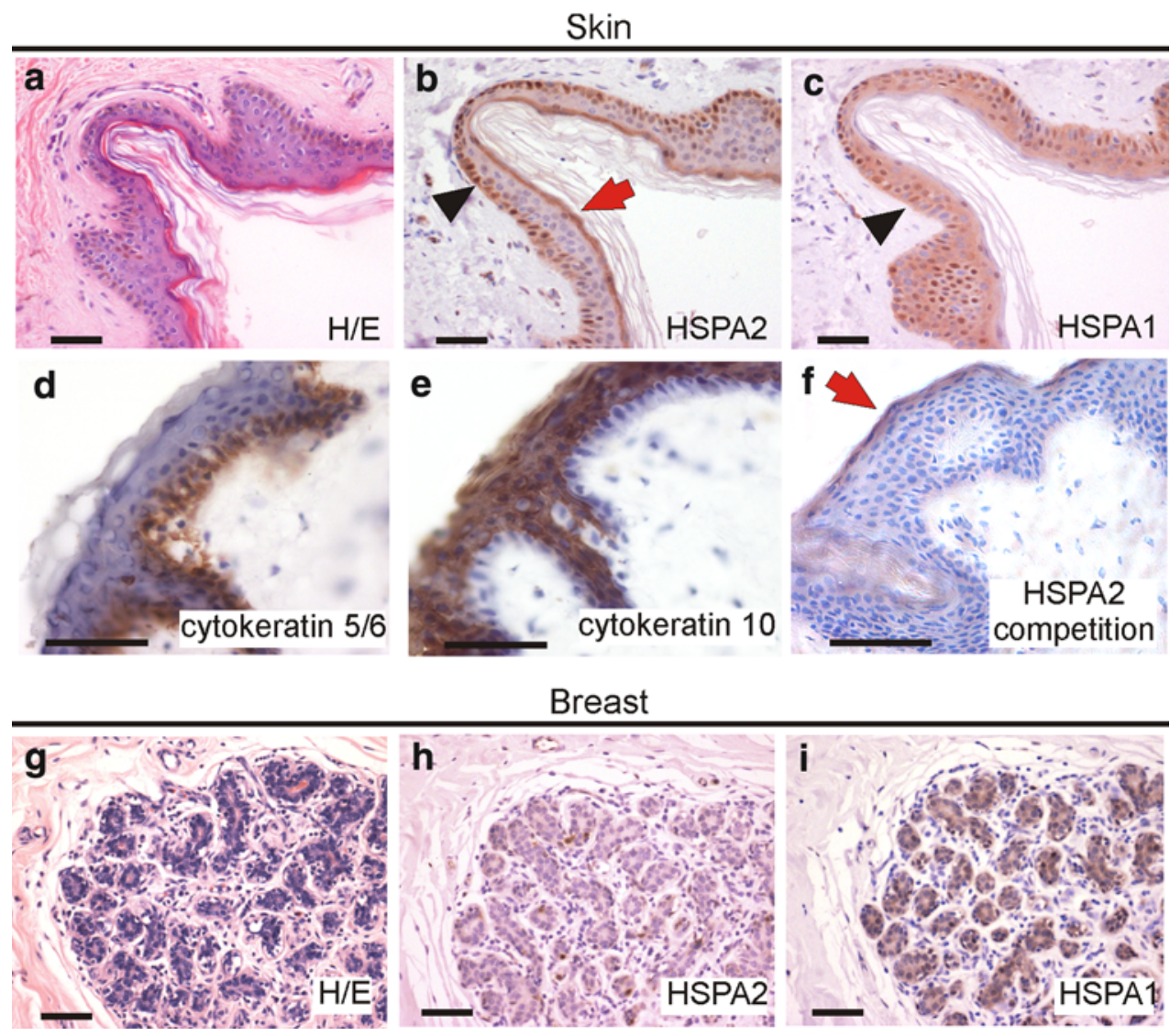

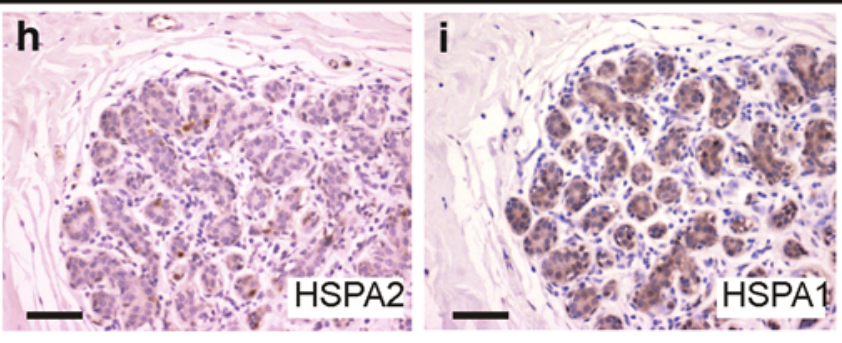

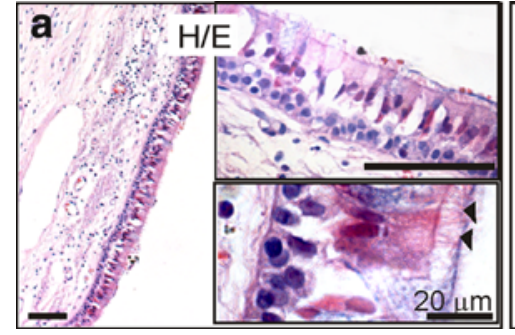
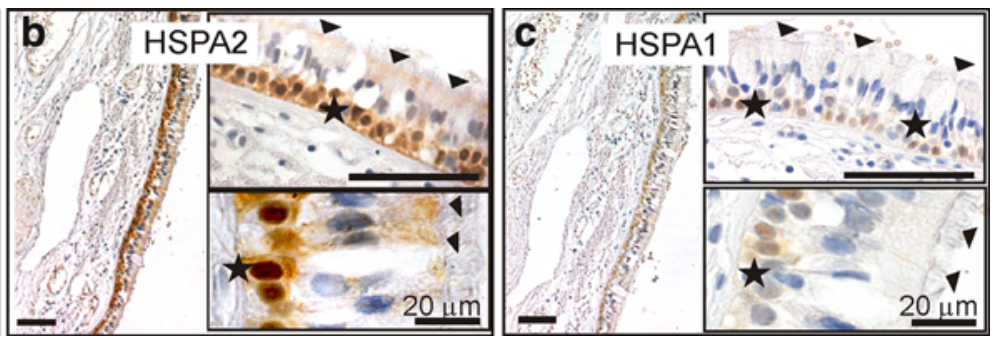

Fig. 3 Detection of HSPA2 and HSPA1 proteins in bronchus. Bronchus section were stained with a H\&E, b anti-HSPA2 antibody, c anti-HSPA1 antibody. Black asterisks goblet cells, black triangles ciliated cells. Bar $100 \mu \mathrm{m}$

Bronchial and lung tissues

The ciliated pseudostratified columnar epithelium lining the respiratory tract is another tissue identified as positive in terms of HSPA2 expression (Fig. 3). We analyzed bronchial (4 spots/1 case) and lung (9 spots/5 cases) tissues, respectively. Strong HSPA2 reaction was found in the cell layer closest to the basement membrane and in goblet cells, which are specialized for secretion of mucus (Fig. 3b). Moderate HSPA2 staining was also detected in ciliated cells in the region nearest to their apical surface (Fig. 3b). In contrast, moderate HSPA1-positive reaction could be detected only in some cells of pseudostratified columnar epithelium and was not observed in goblet cells (compare
Fig. 3b, c). No HSPA2 and HSPA1 expression was detected in lung alveolar cells and connective tissue.

\section{Gastrointestinal tract tissues}

TMAs used in this study contained sections of esophagus ( 1 case/ 4 spots), stomach ( 5 cases/5 spots), colon ( 6 cases $/ 9$ spots) and small intestine ( 1 case/ 4 spots), as well as liver (6 cases/9 spots) and pancreas (6 cases/9 spots). HSPA2 staining was observed in non-keratinizing squamous epithelium of esophagus (Fig. 4b, Online Resource 1). Similarly as for keratinizing epithelium of the skin, strong HSPA2 reaction was observed only in cells constituting stratum basale layer (Fig. 4b). HSPA2 was also detected in 


\section{Esophagus}
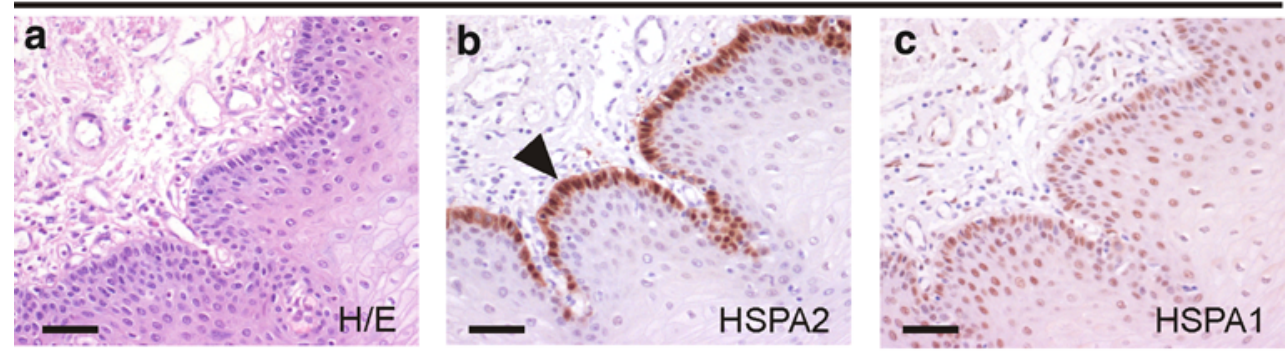

Colon

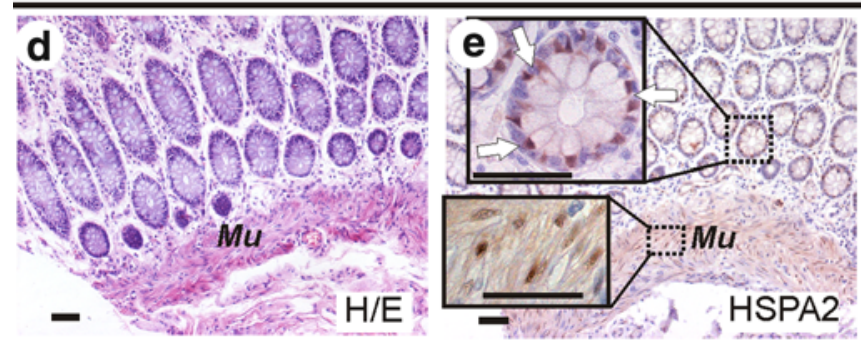

Small intestine
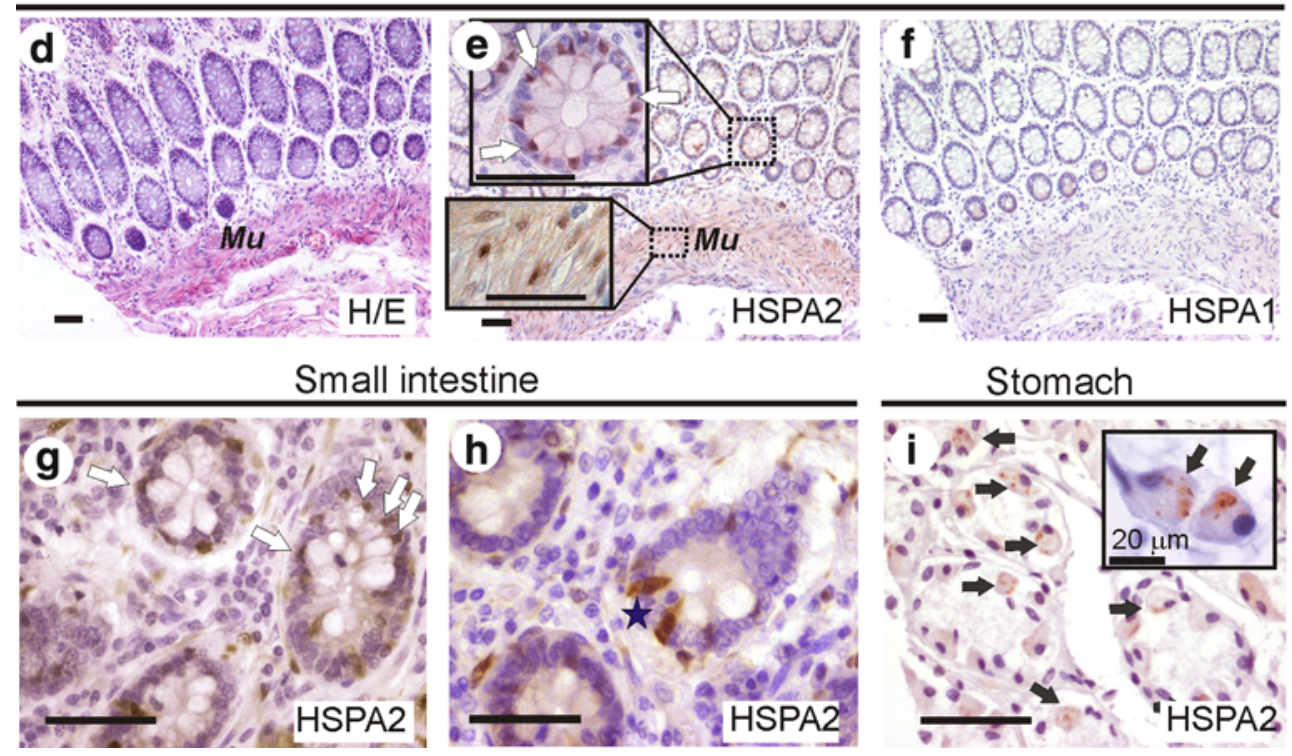

Fig. 4 Detection of HSPA2 and HSPA1 in tissues of gastrointestinal tract. Esophagus cross-section stained with H\&E (a), anti-HSPA2 (b) and anti-HSPA1 (c) antibodies; black arrowhead denotes basal layer of the esophageal epithelium. Colon stained with H\&E (d), antiHSPA2 (e) and anti-HSPA1 (f) antibodies; in e note HSPA2 staining in nuclei of goblet cells (white arrows) and in smooth muscle cells of

intestinal epithelia of the colon and small intestine. In these cases HSPA2 staining was observed in nuclei of goblet cells (Fig. 4e, g) which were also identified as HSPA2-positive in bronchial epithelium. Goblet cells stained with antiHSPA2 antibody were localized closer to the crypts bottom (Fig. 4e, Online Resource 1). In small intestine mucosa, HSPA2 was visible in Paneth cells, which are specialized in secretion of anti-bacterial protein (Fig. 4h). Additionally, in small intestine and colon tissues, HSPA2 staining was observed in cells of smooth muscle fibers of lamina muscularis mucosae (Fig. 4e, Online Resource 1). In the stomach, a spotty HSPA2 staining was observed in epithelial parietal cells, which are specialized in secretion of gastric acid (Fig. 4i). No HSPA2 expression was detected in the pancreas and the liver (not shown).

Differences between HSPA2 and HSPA1 expression patterns were also observed in gastrointestinal tract tissues. While HSPA1 positive cells were distributed in all epithelial muscularis mucose $(M u)$. Small intestine stained with anti-HSPA2 antibody; white arrows point at goblet cells (g) and asterisk at Paneth cells (h). i Detection of HSPA2 in stomach tissue: black arrows indicate parietal cells. Bar $100 \mu \mathrm{m}$. For low magnification $(\times 40)$ pictures see Online Resource 1

layers of esophageal epithelium (Fig. 4c, Online Resource 1), a HSPA2 stained cells were observed in striatum basale layer only (Fig. 4b, Online Resource 1).

No HSPA1 expression was observed in other samples of gastrointestinal tract tissues.

Urinary system and prostate

Investigated TMAs contained samples of kidney cortex (6 cases $/ 9$ spots), bladder ( 5 cases $/ 5$ spots) and prostate (6 cases/9 spots) tissues, respectively. Immunohistochemical study revealed a highly significant difference between expression pattern of HSPA2 and HSPA1 in these tissues. In kidney cortex a moderate HSPA2 staining was detected in distal tubules only, while it was not observed in: other types of tubules, glomeruli and Bowman's capsule (Fig. 5b). The HSPA1 staining intensity varied between kidney cortex samples spotted on TMAs. An example of 


\section{Kidney cortex}
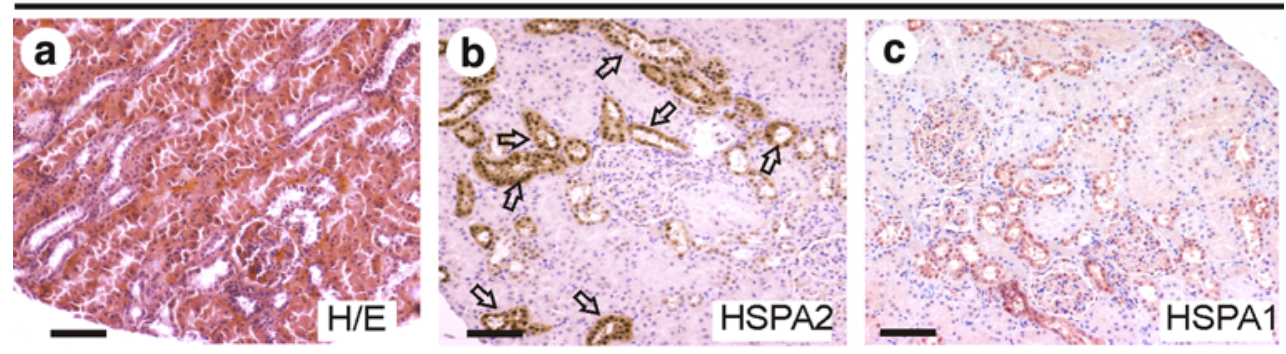

Bladder


Prostate

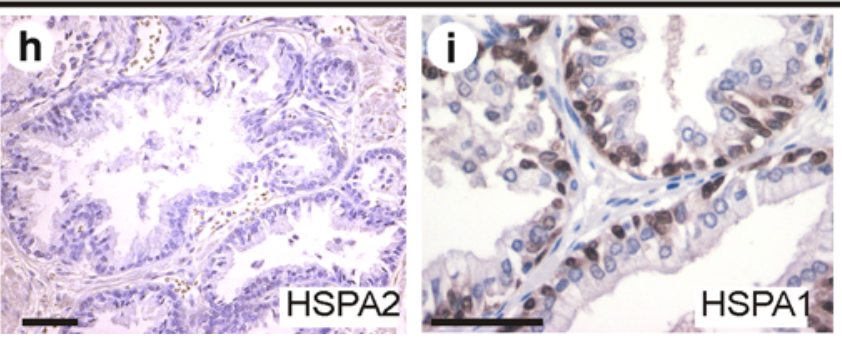

Fig. 5 Expression of HSPA2 and HSPA1 in kidney, bladder and prostate. Kidney cortex stained with H\&E (a), anti-HSPA2 (b) and antiHSPA1 (c) antibodies; white arrows indicate HSPA2 reaction in renal distal tubules. Bladder tissue stained with H\&E (d), anti-HSPA2

the highest intensity staining is shown on Fig. 5c (see also Online Resource 1). In this case moderate HSPA1 staining was observed in cells of glomerulus, Bowman's capsule and renal tubules. In bladder and prostate epithelia strong HSPA1 staining was detected (Fig. 5f, i, Online Resource 1) while no HSPA2 signal was observed (Fig. 5e, h, Online Resource 1). HSPA1 was found in all layers of bladder transitional epithelium (Fig. 5f). In prostatic glandular epithelium, classified as stratified columnar epithelium composed of two functionally and morphologically different cell layers, namely luminal and basal ones, HSPA1 staining was found in basal cells only (Fig. 5i).

\section{Adrenal gland}

In the adrenal gland significant differences between expression pattern of HSPA2 and HSPA1 were also revealed. Moderate HSPA2 staining was restricted to the zona reticularis of the adrenal cortex, the cells which produce precursor androgens (Fig. 6b). In contrast, moderate HSPA1 (e) and anti-HSPA1 (f) antibodies. Gray triangles indicate HSPA1 staining in urothelium. Prostate stained with H\&E (g), anti-HSPA2 (h) and anti-HSPA1 (i) antibodies. Bar $100 \mu \mathrm{m}$. For low magnification $(\times 40)$ pictures see Online Resource 1

signal was shown to be evenly distributed in all three cortical zones (Fig. 6c). Differences are more clearly visible at higher magnification of the zona reticularis (Fig. 6d, e). HSPA2 staining is cytoplasmic and finely granular (Fig. 6d), while HSPA1 staining is nuclear (however, not all nuclei are stained; Fig. 6e). Analysis was done on four spots ( 1 case) of adrenal tissue.

Brain

TMAs used in this study contained samples described as cerebrum tissue (6 cases/9 spots) and cerebellum (1 case/4 spots). None of the analyzed samples showed expression of HSPA1, while all of them were positive when assayed with anti-HSPA2 antibody. A representative result of the immunohistochemical analysis is shown in Fig. 7 (see also Online Resource 1). In cerebellum, strong HSPA2 staining was detected in white matter, while this protein was not found in gray matter or Purkinje cells (Fig. 7c). In the case of cerebrum specimens, a strong HSPA2 positive reaction 




Fig. 6 Detection of HSPA1 and HSPA2 in adrenal gland. Adrenal stained with a H\&E, b anti-HSPA2 and $\mathbf{c}$ anti-HSPA1 antibodies. Detection of HSPA2 (d) and HSPA1 (e) in zona reticularis. f Negative
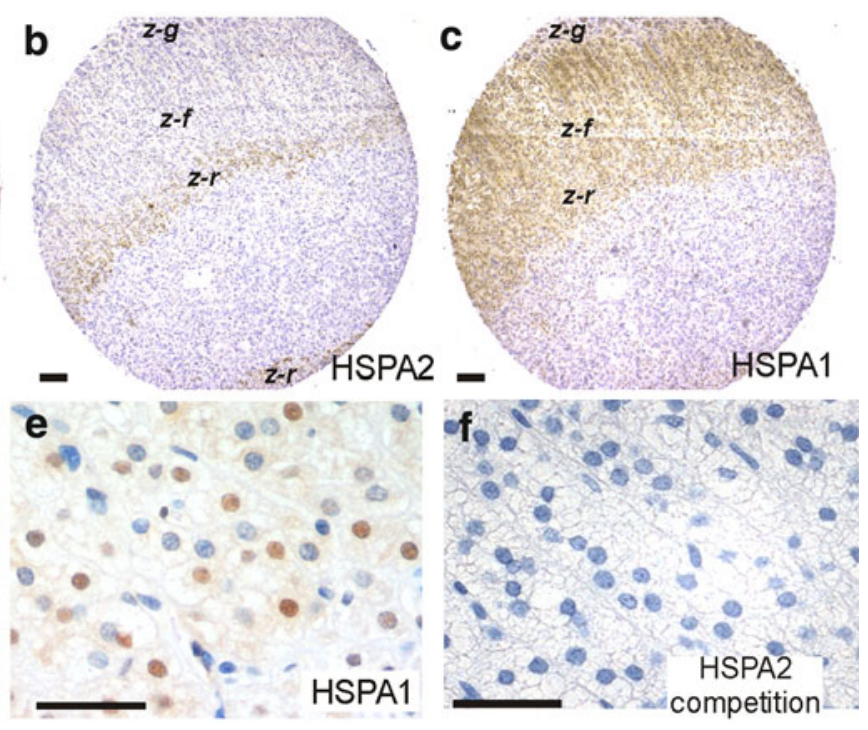

control-result of peptide competition reaction. Co adrenal cortex, $M e$ adrenal medulla, $z-g$ zona glomerulosa, $z-f$ zona fasiculata, $z-r$ zona reticularis. Bar $100 \mu \mathrm{m}$

Other tissues

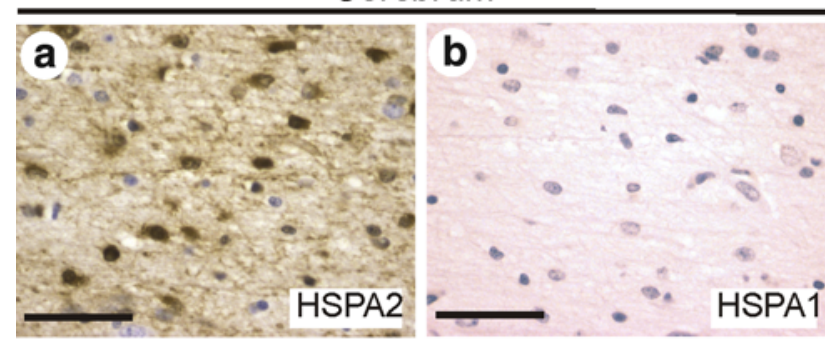

Cerebellum

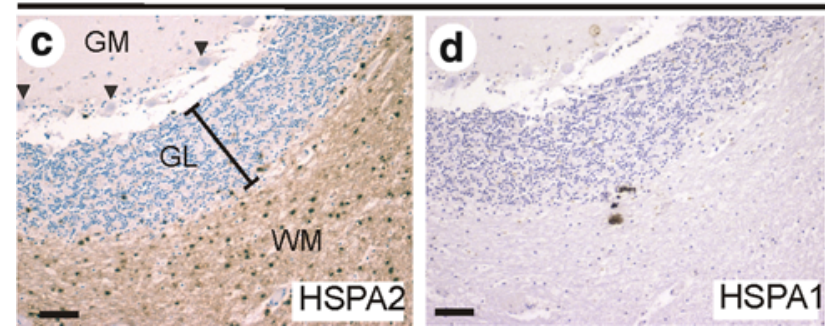

Fig. 7 Detection of HSPA2 and HSPA1 in expression in a, b cerebrum and c, d cerebellum. Tissues were stained with antiHSPA2 (a, c) and anti-HSPA1 (b, d) antibodies. $G M$ gray matter, $G L$ granular layer, $W M$ white matter, black triangles point at Purkinje cells. Bar $100 \mu \mathrm{m}$. For low magnification $(\times 40)$ pictures see Online Resource 1

was observed in glial cells (Fig. 7a). However, due to the small size of tissue spots and due to insufficient histological description supplied by the TMA manufacturer, we were not able to define the brain structure expressing HSPA2. Thus, further studies are required, to describe in more detail HSPA2 expression in brain structures.
Investigated TMAs contained tissues which were identified as negative in terms of expressing both HSPA proteins. Such findings concerned six analyzed tissue types: lymph node (11 cases/14 spots), thyroid (5 cases/5 spots), skeletal muscle ( 1 case/4 spots), spleen ( 1 case/4 spots), diaphragm ( 1 case $/ 4$ spots) and adipose ( 1 case/ 4 spots) tissues. In the case of cardiac muscle tissues ( 1 case/4 spots), which were negative for HSPA2 expression, HSPA1 was detected in blood vessel endothelial cells (not shown). Finally we decided to exclude from the above analysis samples of endometrium and ovary tissues, mainly due to poor quality of the material provided on TMA.

\section{Discussion}

In the present study we determined the expression pattern of HSPA1 and HSPA2 proteins in various normal human tissues using tissue-microarray based immunohistochemical analysis. We selected these two proteins of the HSPA family [nomenclature according to Kampinga et al. (2009)] due to their unique expression properties and very limited or conflicting data on their expression in normal human cells. To our knowledge such a tissue microarray-based survey of normal human tissues for HSPA1 and HSPA2 expression has not been performed so far.

Our study shows for the first time that HSPA2 is expressed in human somatic tissues. HSPA2 was detected in 11 out of 24 tissues analyzed (Table 1). In the case of 
HSPA1 our study revealed its unequivocal presence in 9 of 24 tissues examined (Table 1). The data summarized in the Table 1 show that in normal human tissues the expression pattern of HSPA1 is distinctively different from that of the HSPA2, and both proteins are expressed in a tissue- and cell-type-specific manner to a significant degree.

The human genome encodes more than ten members of the HSPA family, and six of them (HSPA1A, HSPA1B, HSPA1L, HSPA2, HSPA6 and HSPA8) are classified as cytosol/nuclear proteins able to translocate between cytoplasm and nucleus (Kampinga et al. 2009; Brocchieri et al. 2008). Due to their very high similarity HSPA1A and HSPA1B proteins are indistinguishable by a majority of detection methods and here they are collectively called HSPA1. Generally, HSPA1 are regarded as stress-inducible chaperones required for refolding of damaged and unfolded proteins generated by various stressful conditions. However, enhanced expression of HSPA1 at physiological temperature can appear in various pathological states such as myocardial infarction, trauma, sepsis, cerebral ischemia and in various cancers. The HSPA2 gene contains no functional HSE in the promoter and its activity is not enhanced by heat shock. Previous studies performed on a mouse model had described HSPA2 as a testis-specific protein crucial for progression of spermatogenesis (Dix et al. 1996; Govin et al. 2006). Diminished expression of HSPA 2 in human testis was linked to infertility (Huszar et al. 2000). It seems, however, that the established view of HSPA1 and HSPA2 gene expression patterns in human tissues needs revision at present. The common view, that cytosolic stress-inducible HSPA1 protein would play primary role during stress, while cytosolic non-inducible HSPA2 protein performs testis-specific function seems to be an over simplification. Such a conclusion can be substantially supported by data analysis of transcript levels of HSPA family genes derived from the UNIGENE database (http://www.ncbi.nlm.nih.gov/unigene). This resource predicts approximate expression patterns by assessing the relative number of Expressed Sequence Tags (ESTs) per tissue. A similar gene expression resource is the BioGPS database (http://www. biogps.gnf.org), which collects data analyzed on transcript level, obtained through scrutiny of high-density oligonucleotide arrays (Daugaard et al. 2007; Su et al. 2004). The data on HSPA1 and HSPA2 transcription derived from UNIGENE database are presented in Table 1. EST counting clearly shows that both genes can be constitutively transcribed in various normal human tissues. The most satisfying is a significant consistency between our immunohistochemical data concerning expression of the HSPA2 protein and the ESTs data. Also, in the case of HSPAl genes, there is a significant correlation between the presence of both HSPAl transcripts (Table 1) and the expression of corresponding protein (this paper) in a given normal human tissue.

Most of our results concerning the HSPA1 protein are also in agreement with data obtained in several other studies, in which the expression of this protein was investigated in selected normal human tissues. Thus, the constitutive expression of HSPA1 was detected in epithelia lining the skin (Trautinger et al. 1995; Jonak et al. 2009), bronchus (Bonay et al. 1994), bladder (Lebret et al. 2003), prostate (Cornford et al. 2000), breast (Torronteguy et al. 2006) and in adrenal gland (Pignatelli et al. 2003). In the case of kidney, it was shown that HSPA1 expression closely parallels tissue solute concentration (Beck et al. 2000). This observation may explain variable levels of HSPA1 in renal tubules, Bowman capsule and glomeruli, which were detected in our study.

A controversial issue is whether HSPA1 can be expressed in various parts of the human gastrointestinal tract (esophagus, stomach, small intestine, colon) in the absence of exogenous stressful stimuli, and our results did not solve this problem. We detected this protein in normal esophageal epithelium, and its expression pattern was highly similar to that reported by Noguchi et al. (2002). However, in contrast to other reports (Hu et al. 2007; Wang et al. 2007), we did not find HSPA1 in the stomach or colon epithelia. These discrepancies can be explained by the observation that in gastrointestinal tissues HSPA1 expression can be influenced by various factors. For example, in stomach mucosa HSPA1 expression was found to be reduced in individuals infected with Helicobacter pylori or subjected to anti-reflux treatment (Konturek et al. 2001; Wada et al. 2006). It was also shown that in rat gastric mucosa HSPA1 can be induced by stress-related increase in gastric acid content (Otaka et al. 2009). Importantly, it has been also found that HSPA1 can be downregulated by active inflammation of intestinal mucosa (Tao et al. 2009 and ref. therein). In general, the HSPA1 can be expressed at various levels depending on exogenous and endogenous factors which cannot be easily defined [for review see Otaka et al. (2009), Sikora and Grzesiuk (2007)].

Cell-type-specific and differential constitutive expression of HSPA 1 and HSPA 2 proteins in a number of human tissues suggests, that these proteins can perform in vivospecific functions. At present, the issue whether these homologous proteins perform overlapping or distinct functions is highly debatable (Daugaard et al. 2007). So far, only a few studies have been carried out to compare functional properties of HSPA1 and HSPA2. Rohde et al. (2005) found that reduced expression of HSPA1 and HSPA2 affected cancer cell growth and survival in different ways. Next, a more recent study has shown, that exogenous recombinant HSPA1 and HSPA2 proteins, were found to be transported to the lysosomes of cancer cells, but only the 
HSPA1 was able to enhance lysosomal stability (Kirkegaard et al. 2010). On the other hand, it is also possible that different functions of HSPA proteins in vivo are not due to their specific biochemical or client binding properties, but are a result of cell-type-specific regulation of their expression. For example, in rodent testes, the HSPA2 is selectively expressed in pachytene spermatocytes and round spermatids, but not in testicular somatic cells. HSPA2 was found to be a chaperone specifically required for desynapsis of synaptonemal complexes (Allen et al. 1996; Dix et al. 1997), assembly of the functional CDC2/cyclin B1 (Zhu et al. 1997), postmeiotic reorganization of chromatin (Govin et al. 2006). The HSPA2 gene knockout resulted in an arrest of spermatocytes differentiation and division (Dix et al. 1996). In contrast, HSPA1 can be expressed in interstitial somatic cells but not in meiotic cells, even under heat shock (Huang et al. 2001). Thus, due to different regulation of expression, HSPA2 is required for rodent spermatogenesis while HSPA1 is not. However, it is not known whether forced expression of HSPA1 in spermatocytes can functionally replace HSPA2 in testicular cells.

In the epithelia of skin, esophagus and bronchus, both HSPA1 and HSPA2 proteins were found to be expressed. The HSPA2 was almost selectively detected in the nuclei of basal cells, whereas HSPA1 was evenly distributed in cells of all epithelial layers. Thus, such expression patterns raise the question whether there are some cell-type-specific requirements for a particular HSPA protein and whether its specific biochemical activity or such expression pattern reflects only cell-type-specific ability to activate HSPA promoters? Constitutive expression of HSPA1 in epidermis is considered as an inherent protective mechanism against UV radiation (Jonak et al. 2009). It was also shown, that HSPA1 can protect esophageal mucosa in the reflux esophagitis rat model (Izumi et al. 2009). Thus, HSPA1 emerges as a cytoprotective protein in skin and esophagus epithelia. The function of HSPA2 in basal cells is completely unknown, but it is tempting to speculate that this protein can be specifically involved in the proliferation and/or differentiation of epidermal keratinocytes. Such a supposition is to some extent justified by the observation that HSPA2 is highly expressed in tumors (Rohde et al. 2005; Scieglinska et al. 2008; Garg et al. 2010) and it is required for growth of some cancer cells in vitro (Rohde et al. 2005; Garg et al. 2010).

Our study, which shows that human tissues may constitutively and differentially express HSPA1 and HSPA2 proteins, is merely a preliminary, but necessary step towards the determination of their function in normal non-stressed human cells. We hope that our results can provide guidelines for designing experimental models suitable to determine cell- and tissue-type-specific functional differences between HSPA2 and HSPA1 proteins. We believe that our study justifies the conclusion that each tissue, as well as particular cell types, could be viewed as unique systems with respect to the expression of $H S P A$ genes. This implies that for each particular HSPA homolog the regulation of gene transcription and protein function should be experimentally investigated in a most relevant model system and findings pertaining to a given tissue/cell type may not necessarily be applicable to others.

Acknowledgments We thank Ms. K. Klyszcz for skillful technical assistance, Prof A. Żylicz for a gift of recombinant HSPA1 and HSPA8 proteins, Dr R. Nowak for a gift of post-surgical human testes samples, Ms. B. Nikiel for cytokeratin 5/6 and cytokeratin 10 antibodies, Dr K. Lisowska and Dr A. Sochanik for critical reading of the manuscript. This work was supported by a grant from the Polish Ministry of Science and Higher Education (N401 230434) to Z. K.

Open Access This article is distributed under the terms of the Creative Commons Attribution Noncommercial License which permits any noncommercial use, distribution, and reproduction in any medium, provided the original author(s) and source are credited.

\section{References}

Allen JW, Dix DJ, Collins BW, Merrick BA, He C, Selkirk JK, Poorman-Allen P, Dresser ME, Eddy EM (1996) HSP70-2 is part of the synaptonemal complex in mouse and hamster spermatocytes. Chromosoma 104:414-421

Beck FX, Neuhofer W, Müller E (2000) Molecular chaperones in the kidney: distribution, putative roles, and regulation. Am J Physiol Renal Physiol 279:F203-F215

Bonay M, Soler P, Riquet M, Battesti JP, Hance AJ, Tazi A (1994) Expression of heat shock proteins in human lung and lung cancers. Am J Respir Cell Mol Biol 10:453-461

Bonnycastle LL, Yu CE, Hunt CR, Trask BJ, Clancy KP, Weber JL, Patterson D, Schellenberg GD (1994) Cloning, sequencing, and mapping of the human chromosome 14 heat shock protein gene (HSPA2). Genomics 23:85-93

Brocchieri L, Conway de Macario E, Macario AJ (2008) hsp70 genes in the human genome: conservation and differentiation patterns predict a wide array of overlapping and specialized functions. BMC Evol Biol 23:8-19

Calderwood SK, Ciocca DR (2008) Heat shock proteins: stress proteins with Janus-like properties in cancer. Int $\mathbf{J}$ Hyperthermia 24:31-39

Cedenho A, Lima SB, Cenedeze MA, Spaine DM, Ortiz V, Oehninger $S$ (2006) Oligozoospermia and heat-shock protein expression in ejaculated spermatozoa. Hum Reprod 21:1791-1794

Ciocca DR, Calderwood SK (2005) Heat shock proteins in cancer: diagnostic, prognostic, predictive, and treatment implications. Cell Stress Chaperones 10:86-103

Cornford PA, Dodson AR, Parsons KF, Desmond AD, Woolfenden A, Fordham M, Neoptolemos JP, Ke Y, Foster CS (2000) Heat shock protein expression independently predicts clinical outcome in prostate cancer. Cancer Res 60:7099-7105

Daugaard M, Rohde M, Jäättelä M (2007) The heat shock protein 70 family: highly homologous proteins with overlapping and distinct functions. FEBS Lett 581:3702-3710

Dix DJ, Allen JW, Collins BW, Mori C, Nakamura N, Poorman-Allen P, Goulding EH, Eddy EM (1996) Targeted gene disruption of Hsp70-2 results in failed meiosis, germ cell apoptosis, and male infertility. Proc Natl Acad Sci USA 93:3264-3268 
Dix DJ, Allen JW, Collins BW, Poorman-Allen P, Mori C, Blizard DR, Brown PR, Goulding EH, Strong BD, Eddy EM (1997) HSP70-2 is required for desynapsis of synaptonemal complexes during meiotic prophase in juvenile and adult mouse spermatocytes. Development 124:4595-4603

Garg M, Kanojia D, Seth A, Kumar R, Gupta A, Surolia A, Suri A (2010) Heat-shock protein 70-2 (HSP70-2) expression in bladder urothelial carcinoma is associated with tumour progression and promotes migration and invasion. Eur J Cancer 46:207-215

Govin J, Caron C, Escoffier E, Ferro M, Kuhn L, Rousseaux S, Eddy EM, Garin J, Khochbin S (2006) Post-meiotic shifts in HSPA2/ HSP70.2 chaperone activity during mouse spermatogenesis. J Biol Chem 281:37888-37892

Hu S, Ciancio MJ, Lahav M, Fujiya M, Lichtenstein L, Anant S, Musch MW, Chang EB (2007) Translational inhibition of colonic epithelial heat shock proteins by IFN-gamma and TNF-alpha in intestinal inflammation. Gastroenterology 133:1893-1904

Huang L, Mivechi NF, Moskophidis D (2001) Insights into regulation and function of the major stress-induced hsp70 molecular chaperone in vivo: analysis of mice with targeted gene disruption of the hsp70.1 or hsp70.3 gene. Mol Cell Biol 21:8575-8591

Huszar G, Stone K, Dix D, Vigue L (2000) Putative creatine kinase Misoform in human sperm is identified as the 70-kilodalton heat shock protein HspA2. Biol Reprod 63:925-932

Izu H, Inouye S, Fujimoto M, Shiraishi K, Naito K, Nakai A (2004) Heat shock transcription factor 1 is involved in quality-control mechanisms in male germ cells. Biol Reprod 70:18-24

Izumi Y, Otaka M, Takahashi T, Takada M, Shimada Y, Asaoka D, Nagahara A, Itoh H, Watanabe S (2009) Specific induction of a $72-\mathrm{kDa}$ heat shock protein protects esophageal mucosa from reflux esophagitis. Life Sci 84:517-522

Jonak C, Klosner G, Trautinger F (2009) Significance of heat shock proteins in the skin upon UV exposure. Front Biosci 14:47584768

Kampinga HH, Hageman J, Vos MJ, Kubota H, Tanguay RM, Bruford EA, Cheetham ME, Chen B, Hightower LE (2009) Guidelines for the nomenclature of the human heat shock proteins. Cell Stress Chaperones 14:105-111

Kirkegaard T, Roth AG, Petersen NH, Mahalka AK, Olsen OD, Moilanen I, Zylicz A, Knudsen J, Sandhoff K, Arenz C, Kinnunen PK, Nylandsted J, Jäättelä M (2010) Hsp70 stabilizes lysosomes and reverts Niemann-Pick disease-associated lysosomal pathology. Nature 463:549-553

Konturek JW, Fischer H, Konturek PC, Huber V, Boknik P, Luess H, Neumann J, Brzozowski T, Schmitz W, Hahn EG, Domschke W, Konturek SJ (2001) Heat shock protein 70 (HSP70) in gastric adaptation to aspirin in Helicobacter pylori infection. J Physiol Pharmacol 52:153-164

Krawczyk Z, Mali P, Parvinen M (1988a) Expression of a testis-specific hsp70 gene-related RNA in defined stages of rat seminiferous epithelium. J Cell Biol 107:1317-1323

Krawczyk Z, Wisniewski J, Biesiada E (1988b) A rat testis-specific hsp70 gene-related transcript is coded by a novel gene from the hsp70 multigene family. Acta Biochim Pol 35:377-385

Lebret T, Watson RW, Molinié V, O'Neill A, Gabriel C, Fitzpatrick JM, Botto H (2003) Heat shock proteins HSP27, HSP60, HSP70, and HSP90: expression in bladder carcinoma. Cancer 98:970-977

Malusecka E, Zborek A, Krzyzowska-Gruca S, Krawczyk Z (2006) Immunohistochemical detection of the inducible heat shock protein hsp70: a methodological study. J Histochem Cytochem 54:183-190

Mangurten AB, Brader KR, Loos BM, Lee E, Quiroga AI, Bathori J, Lurain JR, Laszlo A, Phillips B (1997) Hsp70 and Hsc70 are preferentially expressed in differentiated epithelial cells in normal human endometrium and ectocervix. Cell Stress Chaperones 2:168-174
Noguchi T, Takeno S, Shibata T, Uchida Y, Yokoyama S, Muller W (2002) Expression of heat shock protein 70 in grossly resected esophageal squamous cell carcinoma. Ann Thorac Surg 74:222226

Noonan EJ, Place RF, Giardina C, Hightower LE (2007a) Hsp70B' regulation and function. Cell Stress Chaperones 12:393-402

Noonan EJ, Place RF, Rasoulpour RJ, Giardina C, Hightower LE (2007b) Cell number-dependent regulation of Hsp70B' expression: evidence of an extracellular regulator. J Cell Physiol 210:201-211

Otaka M, Odashima M, Tamaki K, Watanabe S (2009) Expression and function of stress (heat shock) proteins in gastrointestinal tract. Int J Hyperthermia 25:634-640

Piglowski W, Nowak R, Krawczyk Z, Scieglinska D (2007) The structural and functional analysis of the human HSPA2 gene promoter region. Acta Biochim Pol 54:99-106

Pignatelli D, Ferreira J, Soares P, Costa MJ, Magalhães MC (2003) Immunohistochemical study of heat shock proteins 27,60 and 70 in the normal human adrenal and in adrenal tumors with suppressed ACTH production. Microsc Res Tech 61:315-323

Rohde M, Daugaard M, Jensen MH, Helin K, Nylandsted J, Jaattela M (2005) Members of the heat-shock protein 70 family promote cancer cell growth by distinct mechanisms. Genes Dev 19:570-582

Rosario MO, Perkins SL, O’Brien DA, Allen RL, Eddy EM (1992) Identification of the gene for the developmentally expressed $70 \mathrm{kDa}$ heat-shock protein (P70) of mouse spermatogenic cells. Dev Biol 150:1-11

Sambrook J, Fritsch EF, Maniatis T (1989) Molecular cloning, a laboratory manual, 2nd edn. Cold Spring Harbor Labolatory Press, New York

Schmitt E, Gehrmann M, Brunet M, Multhoff G, Garrido C (2007) Intracellular and extracellular functions of heat shock proteins: repercussions in cancer therapy. J Leukoc Biol 81:15-27

Scieglinska D, Widłak W, Rusin M, Markkula M, Krawczyk Z (1997) Expression of the testis-specific HSP70-related gene (hst70 gene) in somatic non-testicular rat tissues revealed by RT-PCR and transgenic mice analysis. Cell Biol Int 21:813-821

Scieglinska D, Vydra N, Krawczyk Z, Widlak W (2004) Location of promoter elements necessary and sufficient to direct testis-specific expression of the Hst70/Hsp70.2 gene. Biochem J 379:739747

Scieglinska D, Piglowski W, Mazurek A, Malusecka E, Zebracka J, Filipczak P, Krawczyk Z (2008) The HspA2 protein localizes in nucleoli and centrosomes of heat shocked cancer cells. J Cell Biochem 104:2193-2206

Sikora A, Grzesiuk E (2007) Heat shock response in gastrointestinal tract. J Physiol Pharmacol 58:43-62

Son WY, Hwang SH, Han CT, Lee JH, Kim S, Kim YC (1999) Specific expression of heat shock protein HspA2 in human male germ cells. Mol Hum Reprod 5:1122-1126

Su AI, Wiltshire T, Batalov S, Lapp H, Ching KA, Block D, Zhang J, Soden R, Hayakawa M, Kreiman G, Cooke MP, Walker JR, Hogenesch JB (2004) A gene atlas of the mouse and human protein-encoding transcriptomes. Proc Natl Acad Sci USA 101:6062-6067

Tao Y, Hart J, Lichtenstein L, Joseph LJ, Ciancio MJ, Hu S, Chang EB, Bissonnette M (2009) Inducible heat shock protein 70 prevents multifocal flat dysplastic lesions and invasive tumors in an inflammatory model of colon cancer. Carcinogenesis 30:175-182

Torronteguy C, Frasson A, Zerwes F, Winnikov E, da Silva VD, Ménoret A, Bonorino C (2006) Inducible heat shock protein 70 expression as a potential predictive marker of metastasis in breast tumors. Cell Stress Chaperones 11:34-43

Trautinger F, Kindås-Mügge I, Barlan B, Neuner P, Knobler RM (1995) 72-kD heat shock protein is a mediator of resistance to ultraviolet B light. J Invest Dermatol 105:160-162 
Wada I, Otaka M, Jin M, Odashima M, Komatsu K, Konishi N, Matsuhashi T, Horikawa Y, Ohba R, Itoh H, Watanabe S (2006) Expression of HSP72 in the gastric mucosa is regulated by gastric acid in rats-correlation of HSP72 expression with mucosal protection. Biochem Biophys Res Commun 349:611-618

Wang XP, Wang QX, Ying XP (2007) Correlation between clinicopathology and expression of heat shock protein 72 and glycoprotein 96 in human gastric adenocarcinoma. Tohoku J Exp Med 212:35-41

Widlak W, Markkula M, Krawczyk Z, Kananen K, Huhtaniemi I (1995) A 252 bp upstream region of the rat spermatocyte-specific hst70 gene is sufficient to promote expression of the hst70-CAT hybrid gene in testis and brain of transgenic mice. Biochim Biophys Acta 1264:191-200

Widlak W, Winiarski B, Krawczyk A, Vydra N, Malusecka E, Krawczyk Z (2007) Inducible $70 \mathrm{kDa}$ heat shock protein does not protect spermatogenic cells from damage induced by cryptorchidism. Int J Androl 30:80-87
Yagui-Beltran A, Craig AL, Lawrie L, Thompson D, Pospisilova S, Johnston D, Kernohan N, Hopwood D, Dillon JF, Hupp TR (2001) The human oesophageal squamous epithelium exhibits a novel type of heat shock protein response. Eur J Biochem 268:5343-5355

Yesilli C, Mungan G, Seckiner I, Akduman B, Acikgoz S, Altan K, Mungan A (2005) Effect of varicocelectomy on sperm creatine kinase, HspA2 chaperone protein (creatine kinase-M type), LDH, $\mathrm{LDH}-\mathrm{X}$, and lipid peroxidation product levels in infertile men with varicocele. Urology 66:610-615

Zakeri ZF, Wolgemuth DJ, Hunt CR (1988) Identification and sequence analysis of a new member of the mouse HSP70 gene family and characterization of its unique cellular and developmental pattern of expression in the male germ line. Mol Cell Biol 8:2925-2932

Zhu D, Dix DJ, Eddy EM (1997) HSP70-2 is required for CDC2 kinase activity in meiosis I of mouse spermatocytes. Development 124:3007-3014 